\title{
Mothers' beliefs about indigenous and traditional food affordability, availability and taste are significant predictors of indigenous and traditional food consumption among mothers and young children in rural Kenya
}

\author{
Constance Awuor Gewa ${ }^{1, *}$ (1), Agatha Christine Onyango², Frederick Obondo Angano3, \\ Bonnie Stabile ${ }^{4}$, Maction Komwa ${ }^{5}$, Phil Thomas ${ }^{4}$ and Jenna Krall 6 \\ 'Department of Nutrition \& Food Studies, College of Health \& Human Services, George Mason University, Fairfax, VA \\ 22030, USA: ${ }^{2}$ Department of Nutrition \& Health, Maseno University, Maseno, Kenya: ${ }^{3}$ Ministry of Health, Kisumu \\ County, Kenya: ${ }^{4}$ School of Policy, Government, and International Affairs, George Mason University, Fairfax, VA, USA: \\ ${ }^{5}$ Department of Geography and Geolnformation Science, College of Science, George Mason University, Fairfax, VA, \\ USA: 'Department of Global \& Community Health, College of Health \& Human Services, George Mason University, \\ Fairfax, VA, USA
}

Submitted 5 September 2018: Final revision received 26 March 2019: Accepted 17 April 2019; First published online 27 August 2019

\begin{abstract}
Objective: To examine mothers' and young children's consumption of indigenous and traditional foods (ITF), assess mothers' perception of factors that influence ITF consumption, and examine the relationship between perceived factors and ITF consumption.

Design: Longitudinal study design across two agricultural seasons. Seven-day FFQ utilized to assess dietary intake. Mothers interviewed to assess their beliefs about amounts of ITF that they or their young children consumed and on factors that influence ITF consumption levels.

Setting: Seme sub-County, Kenya.

Participants: Mothers with young children.

Results: Less than $60 \%$ of mothers and children consumed ITF at time of assessment. Over $50 \%$ of the mothers reported that their ITF consumption amounts and those of their children were below levels that mothers would have liked for themselves or for their young children. High cost, non-availability and poor taste were top three reasons for low ITF consumption levels. Mothers who identified high cost or non-availability as a reason for low levels of ITF consumption had significantly lower odds of consuming all ITF except amaranth leaves. Mothers who identified poor taste had significantly lower odds of consuming all ITF except green grams and groundnuts. Similar relationships were noted for young children's ITF consumption levels.

Conclusions: A majority of the mothers reported that they and their children did not consume as much ITF as the mothers would have liked. Further studies should examine strategies to improve availability and affordability of ITF, as well as develop recipes that are acceptable to mothers and children.
\end{abstract}

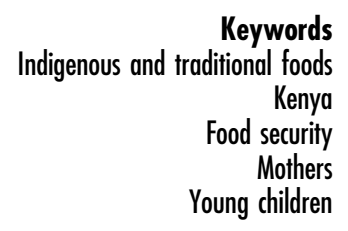

Food and nutrition security exists when all people, at all times, have physical, social and economic access to sufficient, safe and nutritious food which meets their dietary needs and food preferences for an active and healthy life $\mathrm{e}^{(1)}$. Local food production remains one of the key elements to supporting long-term food security in any community. However, for many communities in sub-Sahara Africa, harsh

agroecological conditions characterized by limited rainfall and poor soil conditions leave populations at an everincreasing risk of hunger and food and nutrition insecurity $^{(2)}$. Indigenous and traditional foods (ITF) are foods that are native to a region or have been historically produced in a region ${ }^{(3,4)}$. Unfortunately, most native African foods fell off the food supply during the colonial 
era when new and more marketable crops such as maize and wheat became officially favoured ${ }^{(5)}$. Furthermore, most research investment has focused on crops such as maize, wheat and rice with minimal attention given to the native foods ${ }^{(6)}$. Despite minimal research attention, ITF are often well adapted to the local environment, are less affected by disease and pest problems, and have the potential to contribute to a more stable food supply system in areas with harsh agroecological conditions in Africa. Foods such as sorghum, millet and cassava are drought resistant and perform relatively well in regions with harsh agroecological conditions compared with maize and wheat ${ }^{(7,8)}$. Indigenous vegetables such as amaranthus (Amaranthus spp.) leaves, spider-plant (Cleome gynandra) leaves, jute mallow (Corchorus olitorius), sweet potato (Ipomea batatas) leaves, cassava (Manihot esculenta) leaves, African nightshade (Solanum spp.) leaves and cowpea (Vigna unguiculata) leaves are rich sources of $\beta$-carotene, folates, vitamins $\mathrm{C}$ and $\mathrm{E}, \mathrm{Ca}, \mathrm{Fe}$ and dietary fibre, in addition to antioxidant $\operatorname{activity}^{(3,9)}$.

The most recent estimates show that $26 \%$ of children under the age of 5 years in Kenya are stunted, $11 \%$ are underweight and $4 \%$ are wasted ${ }^{(10)}$. Only $20 \%$ of young children's diets meet the WHO-defined minimal acceptable diet. Over $27 \%$ of women of reproductive age are anaemic, while $23 \%$ of them are overweight and $11 \%$ are obese. These findings illustrate the emerging double burden of malnutrition in Kenya ${ }^{(10)}$. ITF have the potential to contribute to improved dietary diversity and reduce risk of malnutrition among various populations in Kenya. We conducted a study among mothers and young children residing in an area of relatively low levels of agricultural potential to examine their consumption of ITF, assess mothers' perception of factors that influence ITF consumption among mothers and young children, and examine the relationship between perceived factors and reported ITF consumption among mothers and young children.

\section{Methods}

\section{Study design and study population}

The study was a longitudinal study conducted from December 2016 to July 2017 in Seme sub-County of Kisumu County in Kenya. Over $26 \%$ of children under 5 years of age in Kisumu County are stunted, and only $17.6 \%$ of children between the ages of 6 and 23 months consumed recommended minimum meal frequency ${ }^{(11,12)}$. Additionally, food insecurity was identified as a hindrance to recommended breast-feeding practices among mothers residing in the county ${ }^{(11,13)}$. The study area's agricultural zones are classified as semi-humid to semi-arid ${ }^{(14)}$. It is inhabited predominantly by the Luo tribe and is home to multiple indigenous vegetables including Amaranthus spp., C. gynandra, C. olitorius, M. esculenta, Solanum spp., $V$. unguiculata and Gynandropis gynandra, among others $^{(4)}$.
Data were collected to include multiple agricultural seasons, namely hunger (December 2016-January 2017) and harvest season (June-July 2017). The study's inclusion criteria included reproductive-age non-pregnant mothers with singleton young children (12-36 months old) with at least 2-year residency in the study area. Community health workers in the study area were trained to recruit mother-child pairs into the study. All mothers who met the study's criteria and were residing within West Othany and North Ratta administrative locations of Seme subcounty, were approached by trained community health workers and requested to participate in the study. North Ratta is categorized as a semi-humid agroecological zone while West Othany is semi-arid. A total of 220 mothers were approached in the hunger season. Dietary data were collected on 191 mother-child pairs during the hunger season ( $87 \%$ participation rate), of whom 168 participated in the harvest season ( $76 \%$ participation rate). Six enumerators, consisting of nutritionists and graduate nutrition students, were trained to administer informed consent and study questionnaires. Study participants' informed written consent was obtained prior to administering any questionnaires. Community health workers guided enumerators to participants' homes. Because community health workers work with mothers daily, they were asked not to be present during the interviews to eliminate any potential participant bias. Ethical approval for the study was obtained from the Office of Research Subject Protections at George Mason University (number 929857-1) and the Maseno University Ethics Review Committee (number MSU/DRPI/MUERC/ 00317/16). Hospital, medical and nutrition officers were informed in detail about the aim and procedures of the study.

\section{Motber and child's dietary intake}

Dietary intake data were collected in the hunger and harvest seasons. The FAO's women's dietary diversity guide was adapted to develop a $7 \mathrm{~d}$ FFQ that was used to assess mother and children's dietary intake ${ }^{(15)}$. The FFQ consisted of fourteen food groups including: (i) cereals; (ii) white roots and tubers; (iii) other starches; (iv) vitamin A-rich vegetables and tubers; (v) dark-green leafy vegetables (DGLV); (vi) other vegetables; (vii) vitamin-A rich fruits; (viii) other fruits; (ix) organ meats; (x) flesh meats; (xi) eggs; (xii) fish and seafood; (xiii) legumes, nuts and seeds; and (xiv) milk and milk products. Associated foods were listed for each food group. Enumerators called out each food and asked mothers to indicate if they had consumed the food within the last $7 \mathrm{~d}$. Likewise, enumerators called out each food and asked mothers to indicate if their young child had consumed the food within the last $7 \mathrm{~d}$.

A 7 d FFQ was developed to assess mothers' and young children's ITF consumption, specifically millet, sorghum, cassava, green grams, cowpeas, groundnuts, dark-green leafy vegetables (amaranthus, spider plant, 
African nightshade) and the small fish known locally as omena (Rastrineobola argentea). Enumerators called out each food and asked mothers to indicate if they had consumed the food within the last $7 \mathrm{~d}$ and the associated number of days of consumption where applicable. Likewise, enumerators called out each food and asked mothers to indicate if their young child had consumed the food within the last $7 \mathrm{~d}$ and the associated number of days of consumption where applicable.

\section{Assessing mothers' perception of factors that influence consumption of indigenous and traditional foods}

Two questions were used to assess mothers' perception of factors that influenced consumption of ITF by mothers and young children. Because we are not familiar with any recommended ITF intake level, we used amounts of ITF that the mothers would have liked to consume or would have liked their children to consume as reference points when asking these questions. First, mothers were asked: 'Do you think you eat as much (specific ITF) or foods prepared with (specific ITF) as you would like?' This was a close-ended question with a possible response of 'yes' or 'no'. Mothers who responded in the affirmative ('yes') were identified as mothers who believed that they consumed as much ITF as they liked (or desired). Mothers who gave a negative response ('no') were identified as mothers who believed that they did not consume as much ITF as they would have liked. Next, mothers who perceived that they did not consume as much ITF as they would have liked were asked for reasons for lower-than-desired consumption levels: 'Why don't you eat as much (specific ITF) or foods made with (specific ITF) as you would like?' The open-ended nature of this question allowed for different responses which were then grouped into various categories as shown in Figs 1 and 2 and supplemental tables. Similar questions were used to assess mothers' perceptions of young children's ITF intake amounts and associated factors. We use the term 'desired ITF amounts' to refer to amounts of ITF that the mothers would have liked to consume or would have liked their children to consume.

\section{Housebold demographics and socio-economic status}

Information on household demographics and socioeconomic status (SES) was collected once at the beginning of the study. Household members' date of birth, marital status, religion, tribe, sex, number of completed school years and income earning status were recorded. Household size, number of children younger than 5 years old within the household, maternal education level and maternal age were defined from demographic data. Children's birth weight was collected from the maternal child health clinic cards. Additionally, mothers were asked to report on child's maturity status at birth, as indicated on the child's maternal and child health clinic card. The SES questionnaire, which has been used among populations in rural Kenya, accounted for land use, animal ownership, income sources, household expenditures, household possessions, types of houses, types of fuel used in the household, parental literacy, and involvement of parents in leadership and community positions ${ }^{(16,17)}$. A binary scale was used to assign points to binary variables (yes $=1$, no $=0)$ and a sliding scale was used for ratio variables. A composite SES score was developed with a possible range of 4-130 points, whereby a higher score represents a higher level of SES.

Questionnaires were prepared in English and then translated into the local language, Dholuo. All questionnaires were pre-tested and modified before data collection commenced. Interviews were conducted in Dholuo.

\section{Data analysis}

Data analysis was performed using the statistical software package SAS version 9.4. Reported ITF consumption was coded as a binary variable (yes/no) for each ITF of interest (millet, sorghum, cassava, green grams, cowpeas, groundnuts, amaranth leaves, spider-plant leaves and African nightshade leaves). The small fish, omena, was not included in further analysis due to the high rates of consumption recorded ( $>85 \%$ ) among study participants (Table 2). Mothers' reasons for perceived low ITF consumption levels were coded as binary variables (yes/ no). Reasons for perceived low consumption levels were coded as 'no' for mothers who perceived that they or their children consumed desired amounts of ITF. Overall, ITF cost, ITF availability and ITF taste were identified as top three reasons for low levels of consumption and have been explored in detail in the present paper. Descriptive statistics were used to summarize each ITF variable, as well as ITF cost, availability, taste and and demographic variables. Chi-square statistics were used to compare consumption rates and reasons for low ITF consumption levels across seasons. To account for the study's longitudinal design, generalized estimating equation models with an exchangeable correlation structure were used to estimate the association between each perceived reason (ITF cost, ITF availability and ITF taste) and ITF consumption ${ }^{(18)}$. Models were fitted separately for mothers' consumption of each ITF of interest. Each model included ITF cost, ITF availability and ITF taste indicators, and controlled for season (harvest/hunger), household location (North Ratta/West Othany) and SES score, and mothers' age. Models fitted for children's consumption included ITF cost, ITF availability and ITF taste indicators, and controlled for season, household location (North Ratta/West Othany) and SES score, children's age and sex, and breast-feeding indicator. Results have been reported as OR and corresponding $95 \% \mathrm{CI}$. 


\section{Results}

Mothers' age ranged from 18 to 45 years with a mean of 27.58 (SD 6.30) years (Table 1). Children's age ranged from 12 to 36 months with a mean of $22 \cdot 85$ (SD 7.31) months, and 43 and $21 \%$ of the children were still breast-feeding in the hunger and harvest seasons, respectively. Mothers' years of

Table 1 Demographic and socio-economic characteristics of the study participants, Seme sub-County of Kisumu County, Kenya, December 2016-July 2017†,‡

\begin{tabular}{lcccc}
\hline Characteristic & $n$ & $\%$ & Mean & SD \\
\hline Location & & & & \\
$\quad$ West Othany & 191 & 45.0 & - & - \\
$\quad$ North Ratta & 191 & 55.0 & - & - \\
Household size & 190 & - & $5 \cdot 71$ & 1.95 \\
Household socio-economic & 191 & - & 54.0 & 14.0 \\
$\quad$ status score & & & & \\
Household head's highest grade & 183 & - & 7.66 & 2.99 \\
Female-headed household & 189 & $12 \cdot 0$ & - & - \\
Married household head & 188 & $90 \cdot 0$ & - & - \\
Income-earning household head & 188 & $90 \cdot 0$ & - & - \\
Mother's age (years) & 191 & - & 27.6 & 6.30 \\
Mother's highest grade & 186 & - & 7.97 & $2 \cdot 21$ \\
Married mother & 191 & 84.0 & - & - \\
Income-earning mother & 189 & 58.0 & - & - \\
Child's age (months) & 191 & - & 22.9 & 7.31 \\
Young child's sex, female & 191 & 54.0 & - & - \\
\hline
\end{tabular}

†Demographic and socio-economic data were collected during the hunger season. $\ddagger n$ and \% are provided for categorical variables; mean and SD are provided for continuous variables. education ranged from 0 to 14 years with a mean of 7.97 (SD 2.21) years. Twelve per cent of the households were female-headed households.

\section{Dietary consumption patterns}

Mothers' and children's dietary patterns were similar. Nearly all mothers and young children consumed cereals, DGLV, other vegetables, vitamin A-rich fruits, sweets, fish/ seafood and oils/fats food groups at least once within the last $7 \mathrm{~d}$ of the household visit in both seasons. Consumption of vitamin A-rich vegetables and tubers, meats, eggs and dairy foods was low (Table 2). The percentage of study participants who consumed ITF in each food group, with the exception of fish/seafood, was comparatively low (Table 3). Approximately half of mothers and children had consumed sorghum, millet or both in each season. About $30 \%$ had consumed cassava, an ITF tuber, in each season. Approximately $60-70 \%$ had consumed at least one type of indigenous legume, seed or nut at least once within the last $7 \mathrm{~d}$, in both seasons. Green gram and cowpea consumption rates were significantly higher in the harvest season. Approximately $60-70 \%$ of the mothers and children had consumed at least one type of indigenous DGLV, at least once, in each season. The percentage of mothers and children who consumed amaranth or African nightshade leaves was significantly higher during the harvest season. Over $85 \%$ of them consumed omena.

Table 2 Mothers' and 12- to 36-month-old children's consumption patterns in the hunger and harvest seasons, Seme sub-County of Kisumu County, Kenya, December 2016-July 2017

\begin{tabular}{|c|c|c|c|c|c|}
\hline \multirow[b]{2}{*}{ Food group } & \multirow[b]{2}{*}{ Examples of foods } & \multicolumn{2}{|c|}{ Mothers (\%) } & \multicolumn{2}{|c|}{ Children (\%) } \\
\hline & & Hunger & Harvest & Hunger & Harvest \\
\hline All cereals & Maize, sorghum, millet, rice, wheat & 100 & 100 & 99 & 99 \\
\hline White roots and tubers & Irish potatoes, white sweet potatoes, cassava & 52 & 59 & 53 & 61 \\
\hline Other starches & Green bananas & 29 & $18^{*}$ & 30 & $20^{*}$ \\
\hline VAVT & Pumpkins, carrots, orange sweet potatoes & 14 & 18 & 14 & 18 \\
\hline DGLV & Kales, ITF DGLV & 98 & 99 & 97 & 99 \\
\hline Other vegetables & Tomatoes, onions, cabbage, eggplant & 100 & 99 & 98 & 99 \\
\hline VAF & Ripe mango, ripe papaya & 94 & $72^{\star \star \star \star}, \dagger$ & 95 & $74^{\star * * *}, \dagger$ \\
\hline Other fruits & Oranges, lemons, melons, guavas & 51 & $68^{* *}, \dagger$ & 51 & $70^{\star * \star}, \dagger$ \\
\hline Organ meats & Liver, kidney, intestines & 15 & 10 & 15 & 11 \\
\hline Flesh meats & Beef, pork, chicken, lamb, goat & 61 & $28^{\star \star \star \star}, \dagger$ & 59 & $29^{\star * * *}, \dagger$ \\
\hline Eggs & Eggs: chicken, duck, birds, etc. & 46 & 54 & 46 & 55 \\
\hline Fish and seafoods & Fresh or dried fish & 94 & 95 & 95 & 97 \\
\hline Legumes, nuts \& seeds & Dried beans, ITF legumes, nuts and seeds & 80 & $90 * \star \dagger$ & 80 & $90^{\star \star}, \dagger$ \\
\hline Milk and milk products & Milk, cheese, yoghurt & 68 & 69 & 73 & 71 \\
\hline Oil and fats & Oils, fats, butter, margarine, ghee & 95 & $99^{*}$ & 98 & 99 \\
\hline Sweets & Sugar, honey, sodas, juices, candies & 89 & 90 & 89 & 91 \\
\hline Spices, condiments \& beverages & Spices, bullion, tea, coffee, alcohol & 95 & 96 & 95 & 98 \\
\hline Other & & 1 & 0 & 0 & 0 \\
\hline
\end{tabular}

VAVT, vitamin A-rich vegetables and tubers; DGLV, dark-green leafy vegetables; VAF, vitamin A-rich fruits; ITF, indigenous and traditional food.

Millet and sorghum are ITF cereals; cassava is an ITF tuber; green grams, cowpeas and groundnuts are ITF legumes, nuts and seeds; and amaranth, African nightshade and spider-plant leaves are ITF DGLV.

Percentage consuming the food on at least $1 \mathrm{~d}$ within the last $7 \mathrm{~d}$ ( $n 191$ in the hunger season; $n 168$ in the harvest season).

The $\chi^{2}$ test was utilized to compare across-season consumption rates: ${ }^{\star} P<0.05,{ }^{\star \star} P<0.01,{ }^{\star \star \star} P<0.001,{ }^{\star \star \star \star} P<0.0001$.

†Statistically significant after applying Bonferroni correction. 


\section{Mothers' beliefs related to indigenous and traditional foods}

With the exception of amaranth leaves, a majority of mothers believed they and their children consumed lower-than-desired amounts of ITF across both seasons (Tables 4 and 5). In the hunger season about $80 \%$ of mothers believed that they or their children consumed

Table 3 Contribution of indigenous and traditional foods (ITF) to mothers' and 12- to 36-month-old children's diet, Seme subCounty of Kisumu County, Kenya, December 2016-July 2017

\begin{tabular}{|c|c|c|c|c|}
\hline \multirow[b]{2}{*}{ Food group/food } & \multicolumn{2}{|c|}{ Mothers (\%) } & \multicolumn{2}{|c|}{ Children (\%) } \\
\hline & Hunger & Harvest & Hunger & Harvest \\
\hline All cereals & 100 & 100 & 99 & 99 \\
\hline Millet & 30 & 32 & 35 & 32 \\
\hline Sorghum & 35 & 36 & 37 & 38 \\
\hline Millet or sorghum & 48 & 55 & 51 & 55 \\
\hline All white roots and tubers & 52 & 59 & 53 & 61 \\
\hline Cassava & 28 & 22 & 31 & 24 \\
\hline All legumes, nuts and seeds & 80 & 90 & 80 & $90^{\star *}$ \\
\hline Green grams & 26 & $36^{*}$ & 26 & 34 \\
\hline Cowpeas & 35 & $59^{\star \star}, \dagger$ & 38 & $60^{\star \star}, \dagger$ \\
\hline Groundnuts & 24 & 32 & 24 & 33 \\
\hline $\begin{array}{l}\text { At least one indigenous } \\
\text { lequme, nut or seed }\end{array}$ & 60 & $73^{*}$ & 61 & $73^{*}$ \\
\hline All DGLV & 98 & 99 & 97 & 99 \\
\hline Amaranth leaves & 46 & $58^{*}$ & 45 & $56^{*}$ \\
\hline African nightshade leaves & 20 & $36^{\star \star}, \dagger$ & 18 & $35^{\star \star}, \dagger$ \\
\hline Spider-plant leaves & 23 & 29 & 23 & 26 \\
\hline $\begin{array}{l}\text { At least one indigenous } \\
\text { DGLV }\end{array}$ & 59 & $72^{*}$ & 58 & $70^{*}$ \\
\hline All fish and seafood & 94 & 95 & 95 & 97 \\
\hline Omena & 88 & 94 & 85 & $93^{*}$ \\
\hline
\end{tabular}

DGLV, dark-green leafy vegetables.

Millet and sorghum are ITF cereals; cassava is an ITF tuber; green grams, cowpeas and groundnuts are ITF legumes, nuts and seeds; and amaranth, African nightshade and spider-plant leaves are ITF DGLV.

Percentage consuming the food on at least $1 d$ within the last $7 d$ ( $n 191$ in the hunger season; $n 168$ in the harvest season).

The $\chi^{2}$ test was utilized to compare across-season consumption rates: ${ }^{\star} P<0.05$, ${ }^{* \star} P<0.01$.

†Statistically significant after applying Bonferroni correction. lower-than-desired amounts of cowpea seeds, while in the harvest season this percentage dropped significantly to $68 \%$ for mothers and $71 \%$ for children $(P=0.0025$ and $P=0.0155$, respectively).

Mothers identified high cost, non-availability and poor taste as top three reasons for low consumption levels of ITF by study participants (see online supplementary material, Supplemental Tables S1 to S4, and Figs 1 and 2). The percentage of mothers who identified high cost as a reason for low consumption of ITF cereals and tubers ranged from approximately 10 to $25 \%$. The percentage of mothers who identified cost as a reason for low consumption of ITF legumes, seeds and nuts ranged from approximately 10 to $35 \%$, with minimal differences between the hunger and harvest seasons. The percentage of mothers who identified high cost as a reason for low consumption of ITF DGLV was notably lower than that for other ITF. Under $10 \%$ of mothers identified high cost as reason for low consumption of ITF DGLV. A greater proportion of mothers listed non-availability as a reason for low consumption of ITF in the harvest compared with the hunger season. For example, the percentage of mothers who identified non-availability as a reason for low consumption of ITF DGLV ranged from 20 to $38 \%$ in the hunger season. This percentage increased to $30-53 \%$ in the harvest season. The percentage of mothers who identified poor taste as a reason for low consumption was lowest for all ITF except DGLV. Similar patterns were identified with respect to mothers' reasons for young children's low consumption of ITF.

\section{Determinants of consumption of indigenous and traditional foods}

Mothers' consumption of ITF legumes, seeds, nuts and DGLV was significantly lower in the hunger compared with the harvest season (Table 6). Mothers' beliefs about cost,

Table 4 Mothers' beliefs about their own consumption of indigenous and traditional foods (ITF), Seme sub-County of Kisumu County, Kenya, December 2016-July 2017

\begin{tabular}{|c|c|c|c|c|c|c|c|c|c|c|}
\hline \multirow[b]{2}{*}{ Food } & \multicolumn{2}{|c|}{$\begin{array}{l}\text { Consumed } \\
\text { amounts below } \\
\text { desired intake } \\
\text { levels }(\%) \dagger\end{array}$} & \multicolumn{4}{|c|}{$\begin{array}{l}\text { Reasons for consuming } \\
\text { amounts below } \\
\text { desired intake } \\
\text { levels, hunger season (\%) }\end{array}$} & \multicolumn{4}{|c|}{$\begin{array}{l}\text { Reasons for consuming } \\
\text { amounts below } \\
\text { desired intake } \\
\text { levels, harvest season (\%) }\end{array}$} \\
\hline & Hunger & Harvest & $\begin{array}{l}\text { High } \\
\text { cost }\end{array}$ & $\begin{array}{c}\text { Non- } \\
\text { availability }\end{array}$ & $\begin{array}{l}\text { Poor } \\
\text { taste }\end{array}$ & Other & $\begin{array}{l}\text { High } \\
\text { cost }\end{array}$ & $\begin{array}{c}\text { Non- } \\
\text { availability }\end{array}$ & $\begin{array}{l}\text { Poor } \\
\text { taste }\end{array}$ & Other \\
\hline Millet & 64 & 70 & 26 & 21 & 13 & 4 & 24 & 33 & 11 & 2 \\
\hline Sorghum & 55 & 52 & 21 & 15 & 15 & 5 & 10 & 29 & 10 & 4 \\
\hline Cassava & 62 & 68 & 16 & 27 & 14 & 5 & 9 & 46 & 7 & 6 \\
\hline Green grams & 49 & 57 & 31 & 13 & 4 & 1 & 35 & 21 & 1 & 1 \\
\hline Cowpeas & 82 & $68^{\star *}$ & 12 & 48 & 11 & 11 & 11 & 44 & 8 & 5 \\
\hline Groundnuts & 56 & 63 & 27 & 20 & 3 & 6 & 17 & 35 & 3 & 8 \\
\hline Amaranth leaves & 35 & 40 & 3 & 20 & 9 & 3 & 4 & 30 & 7 & 0 \\
\hline $\begin{array}{l}\text { African nightshade } \\
\text { leaves }\end{array}$ & 67 & 64 & 9 & 40 & 15 & 3 & 4 & 48 & 11 & 1 \\
\hline Spider-plant leaves & 65 & 65 & 4 & 36 & 20 & 5 & 3 & 53 & 9 & 1 \\
\hline
\end{tabular}

Percentage of mothers who believed that they did not consume as much ITF as they would have liked ( $n 191$ in hunger season; $n 168$ in harvest season).

†The $\chi^{2}$ test was utilized to compare mothers' perception of low intake across seasons: ${ }^{\star \star} P<0.01$. 
Table 5 Mothers' beliefs about their 12- to 36-month-old children's consumption of indigenous and traditional foods (ITF), Seme sub-County of Kisumu County, Kenya, December 2016-July 2017

\begin{tabular}{|c|c|c|c|c|c|c|c|c|c|c|}
\hline \multirow[b]{2}{*}{ Food } & \multicolumn{2}{|c|}{$\begin{array}{c}\text { Consumed } \\
\text { amounts below } \\
\text { mothers' desired } \\
\text { intake levels } \\
(\%) \dagger\end{array}$} & \multicolumn{4}{|c|}{$\begin{array}{l}\text { Reasons for consuming } \\
\text { amounts below mothers' } \\
\text { desired intake levels, } \\
\text { hunger season (\%) }\end{array}$} & \multicolumn{4}{|c|}{$\begin{array}{l}\text { Reasons for consuming } \\
\text { amounts below mothers' } \\
\text { desired intake levels, } \\
\text { harvest season (\%) }\end{array}$} \\
\hline & Hunger & Harvest & $\begin{array}{l}\text { High } \\
\text { cost }\end{array}$ & $\begin{array}{c}\text { Non } \\
\text { availability }\end{array}$ & $\begin{array}{l}\text { Poor } \\
\text { taste }\end{array}$ & Other & $\begin{array}{l}\text { High } \\
\text { cost }\end{array}$ & $\begin{array}{l}\text { Non } \\
\text { availability }\end{array}$ & $\begin{array}{l}\text { Poor } \\
\text { taste }\end{array}$ & Other \\
\hline Millet & 60 & 67 & 24 & 21 & 13 & 3 & 20 & 33 & 7 & 8 \\
\hline Sorghum & 54 & 51 & 17 & 18 & 13 & 6 & 9 & 26 & 4 & 12 \\
\hline Cassava & 61 & 67 & 14 & 26 & 13 & 8 & 8 & 42 & 9 & 8 \\
\hline Green grams & 52 & 58 & 4 & 15 & 0 & 33 & 29 & 23 & 2 & 4 \\
\hline Cowpeas & 81 & $71^{*}$ & 12 & 47 & 6 & 17 & 10 & 44 & 6 & 11 \\
\hline Groundnuts & 60 & 64 & 22 & 18 & 4 & 15 & 15 & 33 & 4 & 13 \\
\hline Amaranth leaves & 38 & 39 & 2 & 19 & 10 & 7 & 2 & 29 & 6 & 2 \\
\hline $\begin{array}{l}\text { African nightshade } \\
\text { leaves }\end{array}$ & 74 & 69 & 9 & 34 & 20 & 10 & 4 & 45 & 14 & 7 \\
\hline Spider-plant leaves & 73 & 69 & 5 & 31 & 27 & 10 & 3 & 45 & 15 & 6 \\
\hline
\end{tabular}

Percentage of mothers who believed that that their children did not consume as much ITF as the mothers would have liked ( $n 191$ in the hunger season; $n 168$ in the harvest season).

†The $\chi^{2}$ test was utilized to compare perception of low intake across seasons: ${ }^{*} P<0.05$.
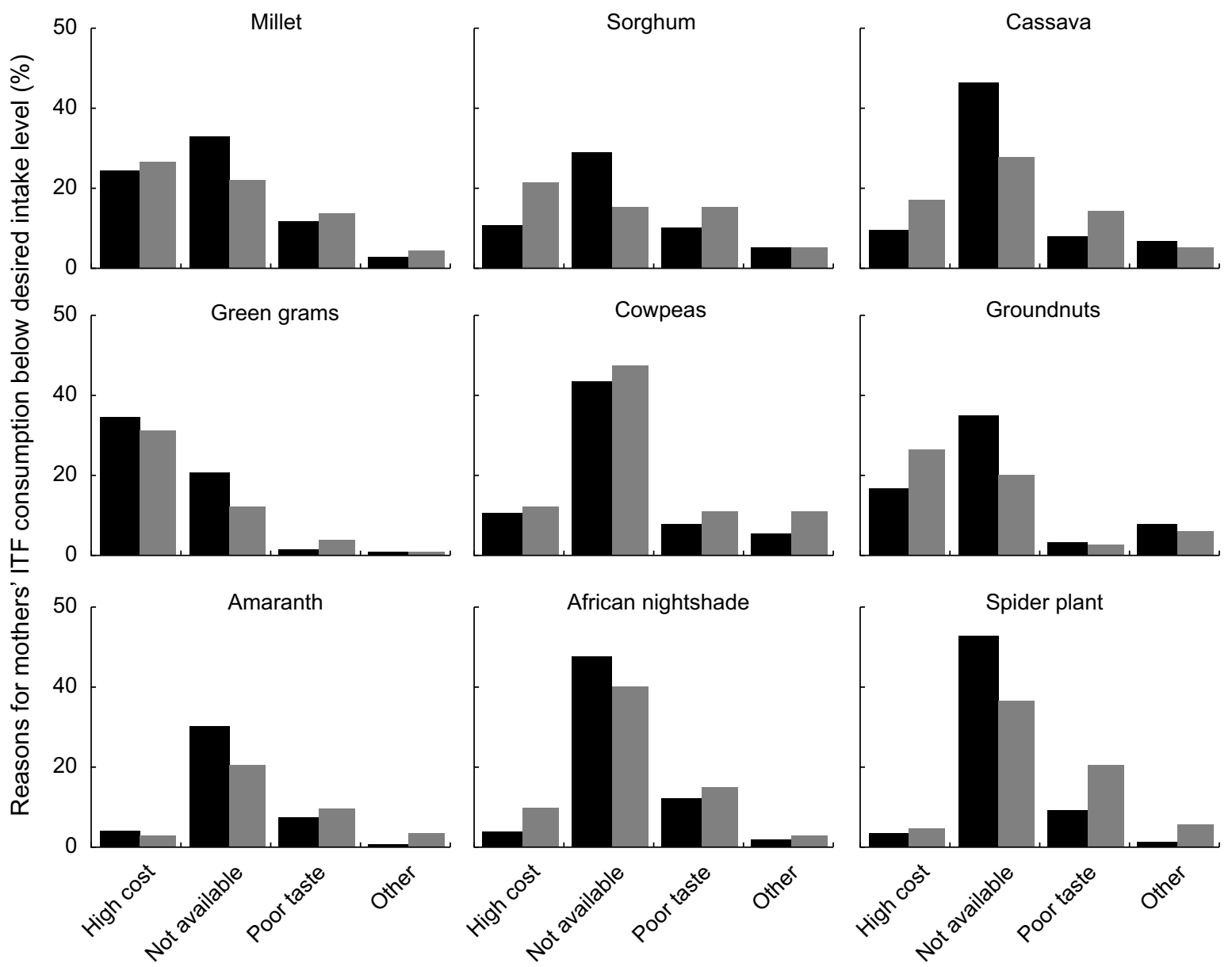

Fig. 1 Mothers' reasons for own consumption amounts of indigenous and traditional foods (ITF) below desired intake levels, by season ( $\square$, harvest season, $n 168$; $\square$, hunger season, $n 191$ ), Seme sub-County of Kisumu County, Kenya, December 2016-July 2017. Bar values represent the percentage of mothers reporting the reason for each food 


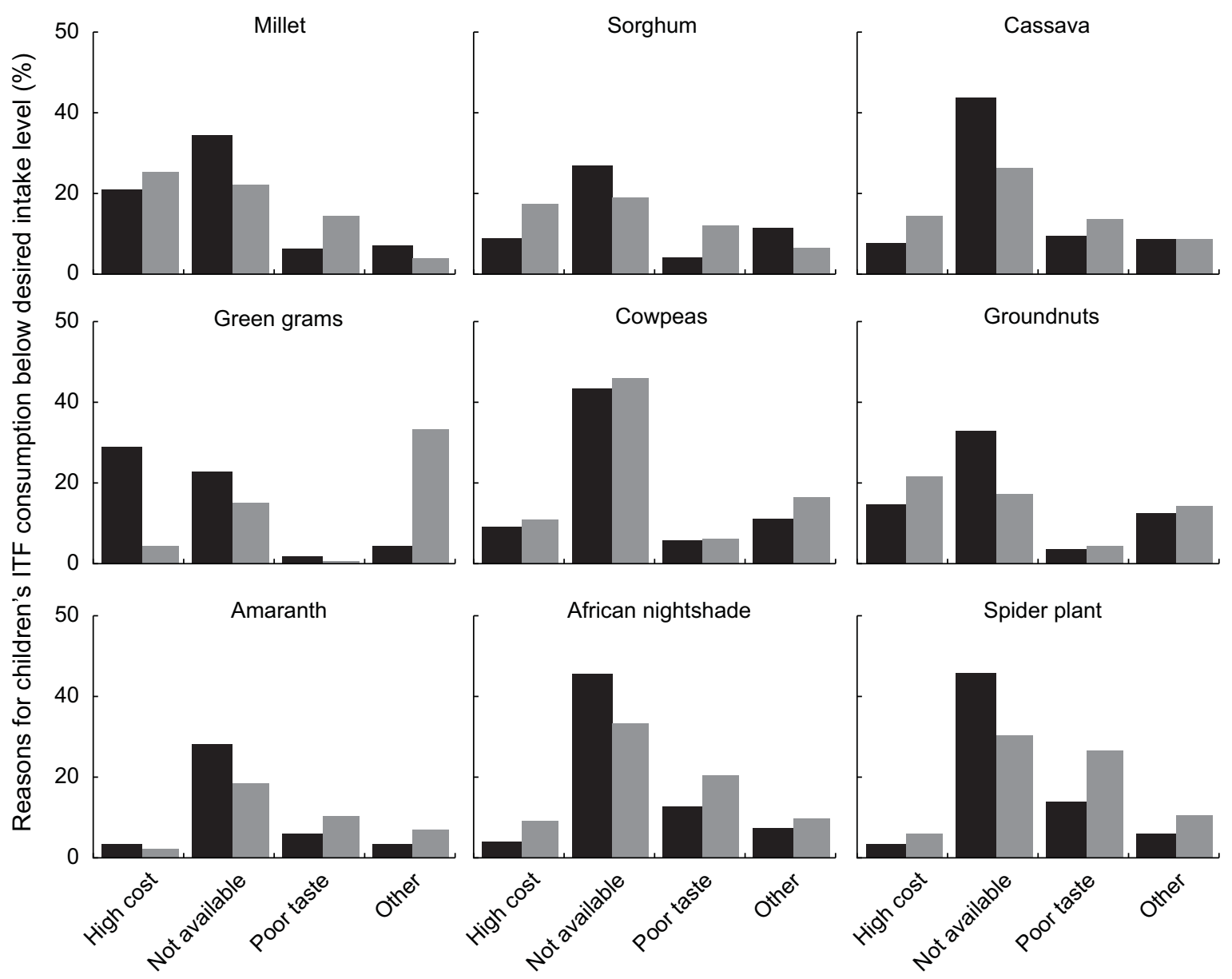

Fig. 2 Mothers' reasons for 12- to 36-month-old children's consumption amounts of indigenous and traditional foods (ITF) below desired intake levels, by season ( $\boldsymbol{\square}$, harvest season, $n 168$; $\square$, hunger season, $n 191$ ), Seme sub-County of Kisumu County, Kenya, December 2016-July 2017. Bar values represent percentage of mothers reporting the reason for each food

Table 6 Mothers' beliefs about costs, availability and taste of indigenous and traditional foods (ITF) as predictors of mothers' ITF consumption, Seme sub-County of Kisumu County, Kenya, December 2016-July 2017

\begin{tabular}{|c|c|c|c|c|c|c|c|c|}
\hline \multirow[b]{2}{*}{ Food } & \multicolumn{2}{|c|}{$\begin{array}{l}\text { Season, } \\
\text { ref. = harvest }\end{array}$} & \multicolumn{2}{|c|}{$\begin{array}{l}\text { High cost, } \\
\text { ref. = high cost not } \\
\text { identified as } \\
\text { a reason }\end{array}$} & \multicolumn{2}{|c|}{$\begin{array}{l}\text { Non-availability, } \\
\text { ref. = non-availability } \\
\text { not identified as } \\
\text { a reason }\end{array}$} & \multicolumn{2}{|c|}{$\begin{array}{l}\text { Poor taste, } \\
\text { ref. = poor taste not } \\
\text { identified as } \\
\text { a reason }\end{array}$} \\
\hline & OR & $95 \% \mathrm{Cl}$ & OR & $95 \% \mathrm{Cl}$ & OR & $95 \% \mathrm{Cl}$ & OR & $95 \% \mathrm{Cl}$ \\
\hline Millet & 0.68 & $0.38,1.19$ & 0.06 & $0.03,0.14$ & 0.04 & $0.02,0.10$ & 0.23 & $0.10,0.52$ \\
\hline Sorghum & 1.05 & $0.61,1.81$ & 0.06 & $0.02,0.17$ & 0.14 & $0.07,0.30$ & 0.14 & $0.06,0.36$ \\
\hline Cassava & 1.23 & $0.73,2.06$ & 0.15 & $0.05,0.41$ & 0.12 & $0.06,0.26$ & 0.22 & $0.08,0.63$ \\
\hline Green grams & 0.42 & $0.25,0.71$ & 0.10 & $0.05,0.20$ & 0.10 & $0.04,0.23$ & 0.10 & $0.01,1.31$ \\
\hline Cowpeas & 0.34 & $0.21,0.55$ & 0.05 & $0.02,0.16$ & 0.20 & $0.11,0.34$ & 0.19 & $0.08,0.44$ \\
\hline Groundnuts & 0.61 & $0.36,1.03$ & 0.06 & $0.02,0.20$ & 0.25 & $0.12,0.49$ & 0.26 & $0.05,1.44$ \\
\hline Amaranth leaves $\dagger$ & 0.44 & $0.26,0.72$ & - & - & 0.12 & $0.07,0.22$ & 0.08 & $0.03,0.19$ \\
\hline Nightshade leaves & 0.43 & $0.26,0.69$ & 0.12 & $0.03,0.48$ & 0.20 & $0.11,0.36$ & 0.32 & $0.14,0.71$ \\
\hline Spider-plant leaves & 0.60 & $0.36,0.98$ & 0.12 & $0.02,0.69$ & 0.16 & $0.09,0.29$ & 0.36 & $0.17,0.78$ \\
\hline
\end{tabular}

Ref., reference category; GEE, generalized estimating equation.

$\mathrm{OR}$ and associated $\mathrm{Cl}$ from each row represent results from one GEE model that includes the ITF cost belief indicator, ITF availability belief indicator, ITF taste belief indicator, season, household socio-economic status score and location, and mother's age unless indicated otherwise.

†GEE model does not include the ITF cost belief indicator, because not enough mothers cited high cost as a reason for not consuming amaranth. 
Table 7 Mothers' beliefs about costs, availability and taste of indigenous and traditional foods (ITF) as predictors of 12- to 36-month-old children's ITF consumption, Seme sub-County of Kisumu County, Kenya, December 2016-July 2017

\begin{tabular}{|c|c|c|c|c|c|c|c|c|}
\hline & \multicolumn{2}{|c|}{$\begin{array}{l}\text { Season, } \\
\text { ref. = harvest }\end{array}$} & \multicolumn{2}{|c|}{$\begin{array}{l}\text { High cost, } \\
\text { ref. = high cost not } \\
\text { identified as } \\
\text { a reason }\end{array}$} & \multicolumn{2}{|c|}{$\begin{array}{l}\text { Non-availability, } \\
\text { ref.= non-availability } \\
\text { not identified as } \\
\text { a reason }\end{array}$} & \multicolumn{2}{|c|}{$\begin{array}{l}\text { Poor taste, } \\
\text { ref. = poor taste not } \\
\text { identified as } \\
\text { a reason }\end{array}$} \\
\hline & OR & $95 \% \mathrm{Cl}$ & OR & $95 \% \mathrm{Cl}$ & OR & $95 \% \mathrm{Cl}$ & OR & $95 \% \mathrm{Cl}$ \\
\hline Millet & 0.98 & $0.58,1.65$ & 0.07 & $0.03,0.14$ & 0.08 & $0.03,0.17$ & 0.21 & $0.09,0.50$ \\
\hline Sorghum & 1.04 & $0.59,1.83$ & 0.06 & $0.02,0.21$ & 0.15 & $0.07,0.32$ & 0.41 & $0.16,1.09$ \\
\hline Cassava & 1.05 & $0 \cdot 62,1 \cdot 77$ & $0 \cdot 10$ & $0.03,0.32$ & $0 \cdot 10$ & $0.04,0.22$ & 0.31 & $0.12,0.80$ \\
\hline Green grams† & 0.43 & $0.24,0.76$ & 0.11 & $0.05,0.23$ & 0.07 & $0.02,0.19$ & - & - \\
\hline Cowpeas & 0.34 & $0.21,0.56$ & 0.05 & $0.02,0.15$ & 0.21 & $0.12,0.37$ & 0.17 & $0.06,0.50$ \\
\hline Groundnuts & 0.50 & $0.28,0.90$ & 0.04 & $0.01,0.17$ & 0.21 & $0.10,0.44$ & 0.38 & $0.08,1.81$ \\
\hline Amaranth leaves $\ddagger$ & 0.46 & $0.26,0.78$ & - & - & 0.09 & $0.05,0.18$ & 0.12 & $0.05,0.28$ \\
\hline Nightshade leaves & 0.35 & $0.21,0.59$ & 0.37 & $0.16,0.87$ & 0.19 & $0.10,0.36$ & 0.25 & $0.11,0.56$ \\
\hline
\end{tabular}

Ref., reference category; GEE, generalized estimating equation.

OR and associated $\mathrm{Cl}$ from each row represent results from one GEE model that includes the ITF cost belief indicator, ITF availability belief indicator, ITF taste belief indicator, season, household socio-economic status and location, children's age, sex and breast-feeding indicator unless indicated otherwise.

TGEE model does not include the ITF taste belief indicator, because not enough mothers cited poor taste as a reason for children not consuming green grams. fGEE model does not include the ITF cost belief indicator, because not enough mothers cited high cost as a reason for children not consuming amaranth

taste and non-availability of ITF were significantly associated with ITF consumption. Mothers who identified high cost as a reason for low levels of ITF consumption had $94 \%$ lower odds of consuming millet, $90 \%$ lower odds of consuming green grams and $88 \%$ lower odds of consuming African nightshade leaves (Table 6). Similar high cost-associated odds were noted for remaining ITF. Associations for non-availability were similar in magnitude to cost, with somewhat attenuated associations for cowpeas, groundnuts and nightshade leaves. For mothers' beliefs about taste, OR of consumption corresponding to most ITF were closer to 1 compared with OR for cost and non-availability. Therefore, beliefs about cost and availability were associated with lower odds of ITF consumption compared with beliefs about taste. Factors associated with ITF consumption among children were similar in magnitude to those of the mothers (Table 7). We were unable to fit models predicting consumption of amaranth using cost for mothers or children, as well as models of green grams using taste for children, because not enough respondents identified cost, taste or availability as reasons for non-consumption.

\section{Discussion}

The current study is one of the few studies that have examined ITF consumption patterns among mothers and young children in low-income countries. ITF have the potential to improve maternal and child nutritional status in communities in low-income countries. However, there is very limited information on ITF consumption patterns and determinants of ITF consumption among vulnerable populations. The current study adds to the literature needed to help guide further action in this area. Overall, low percentages of mothers and young children consumed milk and milk products, eggs, flesh meats and vitamin A-rich vegetables. This consumption pattern is reflective of a diet that may be lacking in good-quality protein as well as micronutrients such as $\mathrm{Ca}, \mathrm{Fe}, \mathrm{Zn}$ and $\beta$-carotene to name a few ${ }^{(19)}$. Sorghum, green grams, cowpeas, cassava, amaranth, black nightshade and spider-plant leaves are rich sources of dietary protein, $\mathrm{Ca}, \mathrm{Fe}, \mathrm{Zn}$ and $\beta$-carotene, and have the potential to improve study participants' dietary quality. Over $50 \%$ of study participants had consumed at least one type of indigenous and traditional legume, nut, seed and DGLV at least once in the previous week. However, the percentage of mothers who reported that they or their children had consumed lower-than-desired ITF amounts remained high for all ITF except amaranth leaves. These results seem to imply that although study participants had access to the ITF examined in the present study, intake levels were low based on the mothers' own intake goals and assessment.

About $50 \%$ of the mothers had consumed millet or sorghum in the previous $7 \mathrm{~d}$. The consumption rate of sorghum reported in the current analysis was lower than that reported among households in South Africa ${ }^{(20)}$. On the other hand, it was higher than that reported among women of reproductive age in India ${ }^{(21)}$. Sorghum and millet consumption in Kenya tends to be lower than that of maize $\mathrm{e}^{(22)}$. Maize is the preferred cereal in the country with an annual consumption amount of $82 \mathrm{~kg} /$ capita compared with only $2.4 \mathrm{~kg} /$ per capita for sorghum and

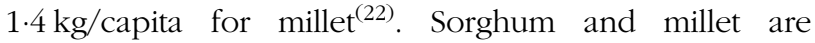
drought-resistant crops that can withstand dry and hightemperature conditions, and have been promoted for production in the arid and semi-arid lands in Kenya ${ }^{(7)}$. However, production has dropped over the years due to multiple factors including poor extension support and lack 
of markets ${ }^{(22)}$. Over $60 \%$ of mothers indicated that they or their children consumed lower-than-desired levels of sorghum or millet. Finger millet flour is commonly used to make porridge which is often served as a weaning food to infants and young children within the study area. Finger millet is one of the most nutritious cereals, with higher levels of nutrient density and a more superior amino acid profile than commonly consumed cereals like rice and wheat ${ }^{(7)}$. Sorghum flour is commonly consumed as porridge and ugali, a stiffer porridge often served with stew or relish, within the study area. Many sorghum varieties grown in the East African region are dark-skinned grains with high tannin content. However, food preparation practices such as fermentation and use in combination with legumes have been shown to reduce tannin content and improve nutrient bioavailability ${ }^{(7,23)}$. Sorghum contains higher levels of the B-vitamins pantothenic acid, niacin, folate and biotin compared with maize, similar levels of riboflavin and pyridoxine and lower amounts of carotene, and in general is a good source of more than twenty micronutrients $^{(7)}$.

Only $20-30 \%$ of the study participants had consumed cassava within the last $7 \mathrm{~d}$. Cassava roots are commonly peeled, washed and boiled prior to consumption among households within the study area. Additionally, the roots are peeled, washed, dried and milled as part porridge and ugali flour. However, cassava production in the study area has declined due to biotic and abiotic factors including the cassava mosaic disease and poor planting material. Smallholder farmers identified lack of knowledge, lack of planting materials, lack of role models, lack of markets and long-maturing crop as reasons for not growing cassava $^{(24)}$. Over $60 \%$ of mothers indicated that they or their children consumed lower-than-desired levels of cassava in each season. Cassava roots are energy dense and due to their drought-tolerant qualities and ability to maintain nutritional value over long periods of time, they have the potential to reduce hunger among populations living in arid and semi-arid lands of Kenya ${ }^{(8,25)}$. Although not commonly consumed in the study area, cassava leaves are rich in $\mathrm{Fe}, \mathrm{Zn}, \mathrm{Mn}, \mathrm{Mg}$ and $\mathrm{Ca}$, and have the potential of improving dietary quality within the study area ${ }^{(8)}$.

Although $80 \%$ of the mothers and young children had consumed legumes and nuts within the week during the hunger season, less than $40 \%$ of them had consumed cowpea seeds, green grams or groundnuts within the same period. Mothers' consumption of green grams and cowpeas ranged from $35-51 \%$ in the hunger season to $60-69 \%$ in the harvest season. In comparison, only $21 \%$ of women of reproductive age consumed pulses in India ${ }^{(21)}$. It is important to note that consumption levels, especially that of cowpea seeds, increased during the harvest season. Cowpea seeds are nutrient rich, with $22-24 \%$ of the dry seeds being good-quality protein. They provide an affordable protein source compared with other animal-source protein foods, with the cost coming to about one-fifth that of eggs or beef, and are also good sources of dietary fibre and some minerals ${ }^{(26,27)}$. Cowpea plants are fast maturing, drought tolerant and adapted to poor soils. Although sub-Sahara Africa accounts for over $90 \%$ of the global cowpea-harvested area and yield, most of this production is concentrated in West Africa with Niger and Nigeria identified as top cowpea-producing countries in the world. Cowpea production and yield, although increasing over the years, are relatively low in the East African region. Kenya and Tanzania have been ranked sixth and seventh with only 0.15 million hectares of harvested cowpea area compared with 4.76 and 4.40 million hectares in Niger and Nigeria, respectively ${ }^{(28)}$. Cowpea consumption levels are relatively low among populations in East Africa, with a cowpeas making up only $5 \%$ of the per capita pulse consumption compared with West Africa where cowpeas constitute $88 \%$ of the per capita pulse consumption. Dry beans are the legumes of choice in Kenya with 0.83 million hectares of harvested dry bean area. Dry beans constitute $>50 \%$ of the per capita pulse consumption in East Africa. However, $70 \%$ of mothers in the current study indicated that they or their children consumed lower-than-desired amounts of cowpea seeds within their diet.

Green gram is drought tolerant and has been promoted as a dry land crop in Kenya ${ }^{(29,30)}$. Green grams are a good source of high-quality protein, dietary fibre and minerals such as $\mathrm{K}$ and $\mathrm{P}^{(27,29)}$. One hundred grams of dry green grams provides about $24 \mathrm{~g}$ of protein. Although green gram production in Kenya has increased over the years, production levels do not measure up to that of kidney beans. Over 259000 hectares was under green gram production in in 2014 compared with over 1 million hectares under dry/ common bean production in the country ${ }^{(31)}$. Green grams have been historically produced in the study area, Seme sub-County. However, the number of households engaging in green gram production has reduced drastically over the years. Families in the study area often consume green grams as a stew served with rice, ugali or chapati (flat bread). Only 26-36\% of the mothers and children had consumed green grams within the week and over $50 \%$ of the mothers indicated that they or their children consumed lower-than-desired levels of green grams.

Virtually all of the mothers and young children had consumed DGLV within the week. However, less than $40 \%$ of them had consumed either spider-plant or African nightshade leaves within the same period. Mothers' consumption of the ITF DGLV ranged from $20-46 \%$ in the hunger season to $30-59 \%$ in the harvest season. In comparison, only $20 \%$ of women of reproductive age consumed indigenous green leafy vegetables in India ${ }^{(21)}$. Amaranth leaves were most commonly consumed of all three indigenous DGLV examined in the current study. Less than $40 \%$ of the mothers indicated that they or their children consumed lower-than-desired amounts of amaranth leaves in their diet. On the other hand, over 
$60 \%$ of the mothers indicated that they or their children consumed lower-than-desired amounts of spider-plant or African nightshade leaves in their diet. Amaranthus (Amaranthus spp.) leaves, spider-plant (C. gynandra) leaves and African nightshade (Solanum spp.) leaves are rich sources of $\beta$-carotene, folates, vitamins $\mathrm{C}$ and $\mathrm{E}, \mathrm{Ca}$, Fe and dietary fibre, in addition to antioxidant activity ${ }^{(4,9)}$. Amaranth and African nightshade plants perform well in a wide range of climatic conditions. Spider plants are hardy plants that can grow in relatively poor soils and in a wide range of environmental conditions. All three DGLV can be found growing in the wild or in cultivated plots within the study area.

Mothers' beliefs about cost emerged as a significant predictor of mothers' and young children's consumption of all ITF examined in the present study with the exception of amaranth leaves. Mothers who believed that high cost of ITF was a reason for low levels of ITF consumption were associated with significantly lower odds of consuming ITF, and the same applied to their children. Although studies that have examined determinants of ITF consumption are relatively few, results from these studies have been mixed thus far. For example, Cloete and Idsardi reported that over $46 \%$ of their South African study sample households identified affordability as an important driver of indigenous food consumption ${ }^{(20)}$. A more recent study that included only households from a rural community in South Africa showed that only $10 \%$ of the households surveyed considered African leafy vegetables (ALV) to be cheap vegetables and only $10 \%$ of those interviewed labelled ALV as a poor man's food ${ }^{(32)}$. While some previous studies have indicated that ITF were more likely to be consumed by lower-income households, results from the current study do not seem to support that view ${ }^{(20,33)}$. The current study's results align with those of Taruvingha and Nengovhela ${ }^{(32)}$. Possible differences may lie in the studies' sample composition. The study conducted by Taruvingha and Nengovhela and the current study focused only on rural households, while other studies included a mix of rural and urban households. Individuals' perception on ITF affordability might vary across certain demographic indicators.

Mothers' beliefs about ITF non-availability emerged as a significant predictor of mothers' and young children's consumption of all ITF examined in the present study. Mothers who reported that ITF non-availability was a reason for low levels of ITF consumption were associated with significantly lower odds of consuming ITF, and the same applied to their children. These results seem to align with those reported in previous studies. Cloete and Idsardi reported that $46 \%$ of households identified non-availability of ITF as a motivator for non-consumption of these foods ${ }^{(20)}$. More recently, Taruvingha and Nengovhela showed that an increase in market availability of ALV was associated with increased log odds of consuming ALV among households in South Africa. Furthermore, individuals who produced ALV were more likely to consume them ${ }^{(32)}$.
It is important to note that less than $20 \%$ of mothers identified taste as a reason for low levels of ITF consumption for most of the listed foods. Despite this, mothers' beliefs about ITF taste were associated with significantly lower odds of consuming six of the nine ITF examined in the present study. Thus, taste preference should not be ignored when promoting production and consumption of ITF in the study area. Results from the current study agree with those of Taruvingha and Nengovhela who reported that individuals who believed that ALV had a poor taste were less likely to consume them ${ }^{(32)}$.

The current study contributes to an identified gap in the food and nutrition literature. Based on the existing literature, we strongly believe that ITF have the potential to improve food security, dietary diversity and nutritional status of mothers and children in areas that have routinely been referred to as areas of 'low agricultural potential'. Although we are not familiar with any recommended ITF intake levels, the present study shows that ITF consumption levels among mothers and children are relatively low compared with that of contemporary crops like maize and kidney beans. Additionally, a majority of mothers in the study area believed that they consumed lower amounts than they would have liked for themselves and their young children. Beliefs about cost, non-availability and taste were significant predictors of ITF consumption in the study area. Although our study was limited to mothers' perceptions, it is important to note that one's perceptions of factors such as food prices are likely to be influenced by one's prior experience ${ }^{(34)}$. Thus, mothers' perceptions about ITF cost and non-availability reported in the present study are likely to be a good reflection of their reality.

The Government of Kenya's food and nutrition security policy acknowledged that unsustainable landmanagement practices in arid and semi-arid lands had led to the degradation of natural resources, significant loss of biodiversity, and adversely affected traditional sources of food, income and other basic needs for rural communities in Kenya ${ }^{(35)}$. The policy also recognized that the production of many traditional crops had given way to modern crops and changing diets. The current study's results may be reflective of the current agricultural practices in Kenya. However, we cannot be certain since the current analysis did not focus on agricultural practices and policies. Promotion and support of production of ITF in Kenya are relatively minimal compared with that invested in commodities such maize and bean production ${ }^{(20,28)}$. Efforts to increase production of sorghum, cassava, green grams and cowpeas are in their early stages ${ }^{(24,30,31)}$. Projects that have promoted production of indigenous vegetables have been implemented in areas of medium to high agricultural potential, at the exclusion of populations living in arid and semi-arid parts of the country ${ }^{(33,36,37)}$. Factors such as access to extension services, markets and market information, labour, quality seeds and planting 
material, farm inputs and credit have been shown to influence production of cassava, sorghum and indigenous vegetables in Seme sub-County and other communities in Kenya $^{(22,24,38-41)}$. Future efforts should address these factors and work with community members to develop and promote recipes that utilize ITF and are acceptable to mothers and young children. Our results show that mothers' and young children's dietary patterns were quite similar. Thus, influencing mothers' diets would likely influence young children's diets.

\section{Acknowledgements}

Financial support: This work was supported by George Mason University Provost Multidisciplinary Grant Award. No funding body had any role in the study design, data collection and analysis, decision to publish, or preparation of the manuscript. Conflict of interest: The authors declare no conflicts of interest with respect to the research, authorship and/or publication of this article. Autborship: C.A.G. formulated the study, designed and conducted the research, analysed the data and wrote the paper. A.C.O. facilitated the field activities, conducted the research and edited the paper. F.O.A. facilitated the field activities, conducted the research and edited the paper. B.S. formulated the study, designed the research and edited the paper. M.K. formulated the study, designed the research and edited the paper. P.T. formulated the study, designed the research and edited the paper. J.K. analysed the data and wrote the paper. Ethics of buman subject participation: This study was conducted according to the guidelines laid down in the Declaration of Helsinki and all procedures involving human subjects were approved by the Office of Research Subject Protections at George Mason University and the Maseno University Ethics Review Committee. Written informed consent was obtained from all subjects.

\section{Supplementary material}

To view supplementary material for this article, please visit https://doi.org/10.1017/S1368980019001848

\section{References}

1. Food and Agriculture Organization of the United Nations (2001) The state of food insecurity in the world 2001. http:// www.fao.org/docrep/003/y1500e/y1500e00.htm (accessed April 2016).

2. Thomas P (2014) The elusive goal of eliminating global hunger: progress and challenges. World Med Health Policy 6, 158-165.

3. Yang R-Y \& Ojiewo C (2013) African nightshades and African eggplants: taxonomy, crop management, utilization, and phytonutrients. In African Natural Plant Products. vol. II: Discoveries and Challenges in Chemistry, Health, and Nutrition, pp. 137-165 [HR Juliani, JE Simon and C-T Ho, editors]. Washington, DC: American Chemical Society; available at http://pubs.acs.org/doi/abs/10.1021/bk-2013-1127. ch011

4. Maundu P (1997) The status of traditional vegetable utilization in Kenya. In Traditional African Vegetables. Proceedings of the IPGRI International Workshop on Genetic Resources of Traditional Vegetables in Africa: Conservation and Use, 29-31 August 1995, ICRAF-HQ, Nairobi, Kenya, pp. 66-75. Rome: International Plant Genetic Resources Institute.

5. National Research Council (2006) Lost Crops of Africa. vol. II: Vegetables. Washington, DC: The National Academies Press; available at https://www.nap.edu/catalog/11763/lost-cropsof-africa-volume-ii-vegetables (accessed May 2017).

6. Jerop R, Dannenberg P, Owuor G et al. (2018) Factors affecting the adoption of agricultural innovations on underutilized cereals: the case of finger millet among smallholder farmers in Kenya. Afr J Agric Res 13, 1888-1900.

7. National Research Council (1996) Lost Crops of Africa. vol. I: Grains. Washington, DC: National Academies Press; available at https://www.nap.edu/catalog/2305/lost-cropsof-africa-volume-i-grains (accessed May 2017).

8. Montagnac JA, Davis CR \& Tanumihardjo SA (2009) Nutritional value of cassava for use as a staple food and recent advances for improvement. Compr Rev Food Sci Food Saf 8, 181-194.

9. Yang R-Y, Fischer S, Hanson PM \& Keatinge JDH (2013) Increasing micronutrient availability from food in sub-Saharan Africa with indigenous vegetables. In African Natural Plant Products. vol. II: Discoveries and Challenges in Chemistry, Health, and Nutrition, pp. 231-254 [HR Juliani, JE Simon and C-T Ho, editors]. Washington, DC: American Chemical Society; available at http://pubs.acs. org/doi/abs/10.1021/bk-2013-1127.ch015

10. Kenya National Bureau of Statistics, Ministry of Health/Kenya, National AIDS Control Council/Kenya et al. (2015) Kenya Demographic and Health Survey 2014. Rockville, MD: Kenya National Bureau of Statistics, Ministry of Health/ Kenya, National AIDS Control Council/Kenya, Kenya Medical Research Institute, National Council for Population and Development/Kenya, and ICF International.

11. Kenya National Bureau of Statistics (2013) Nyanza Province Multiple Indicator Cluster Survey 2011, Final Report. Nairobi: Kenya National Bureau of Statistics.

12. Gewa CA \& Leslie TF (2015) Distribution and determinants of young child feeding practices in the East African region: demographic health survey data analysis from 2008-2011. J Health Popul Nutr 34, 6.

13. Gewa CA, Oguttu M \& Savaglio L (2011) Determinants of early child-feeding practices among HIV-infected and noninfected mothers in rural Kenya. J Hum Lact 27, 239-249.

14. Kamoni PT, Gicheru PT, Wokabi SM et al. (2007) Predicted soil organic carbon stocks and changes in Kenya between 1990 and 2030. Agr Ecosyst Environ 122, 105-113.

15. Food and Agriculture Organization of the United Nations \& USAID's Food and Nutrition Technical Assistance III Project (FANTA) (2016) Minimum Dietary Diversity for Women: A Guide for Measurement. Rome: FAO; available at http://www.fao.org/3/a-i5486e.pdf

16. Neumann CG, Bwibo NO, Murphy SP et al. (2003) Animal source foods improve dietary quality, micronutrient status, growth and cognitive function in Kenyan school children: background, study design and baseline findings. I Nutr 133, 11 Suppl. 2, 3941S-3949S.

17. Gewa CA \& Chepkemboi J (2016) Maternal knowledge, outcome expectancies and normative beliefs as determinants 
of cessation of exclusive breastfeeding: a cross-sectional study in rural Kenya. BMC Public Health 16, 243.

18. Liang K-Y \& Zeger SL (1986) Longitudinal data analysis using generalized linear models. Biometrika 73, 13-22.

19. Murphy SP, Gewa C, Grillenberger M et al. (2007) Designing snacks to address micronutrient deficiencies in rural Kenyan schoolchildren. J Nutr 137, 1093-1096.

20. Cloete PC \& Idsardi EF (2013) Consumption of indigenous and traditional food crops: perceptions and realities from South Africa. Agroecol Sust Food 37, 902-914.

21. Ghosh-Jerath S, Singh A, Magsumbol MS et al. (2016) Contribution of indigenous foods towards nutrient intakes and nutritional status of women in the Santhal tribal community of Jharkhand, India. Public Health Nutr 19, 2256-2267.

22. Gierend A \& Orr A (2015) Consumer demand for sorghum and millets in eastern and southern Africa: Priorities for the CGIAR Research Programme for Dryland Cereals. http:// oar.icrisat.org/9013/1/ISEDPS_35.pdf (accessed April 2018).

23. Abdualrahman MAY, Ma H, Yagoub AEA et al. (2016) Nutritional value, protein quality and antioxidant activity of Sudanese sorghum-based kissra bread fortified with bambara groundnut (Voandzeia subterranea) seed flour. J Saudi Soc Agric Sci 18, 32-40.

24. Mulu-Mutuku MW, Odero-Wanga DA, Ali-Olubandwa A et al. (2013) Commercialisation of traditional crops: are cassava production and utilisation promotion efforts bearing fruit in Kenya?J Sustain Dev 6, issue 7, 48-58.

25. El-Sharkawy M (2004) Cassava biology and physiology. Plant Mol Biol 56, 481-501.

26. Gómez C \& Mejía D (2004) Coupea: Post-Harvest Operations. Rome: FAO.

27. US Department of Agriculture (n.d.) USDA Food Composition Databases. https://ndb.nal.usda.gov/ndb/ (accessed March 2018)

28. Akibode CS (2011) Trends in the production, trade, and consumption of food-legume crops in sub-Saharan Africa. MS Thesis, Michigan State University; available at https:// ageconsearch.umn.edu/bitstream/114247/2/Final\%20draft \%20submiited\%20to\%20the\%20AFRE.pdf

29. Kilimo Trust (2017) Characteristics of markets for green grams in the East African Community. https://www. kilimotrust.org/reacts/files/GreenGrams_markets_X-tisation. pdf (accessed August 2019).

30. Food and Agricultural Research Management (FARM AFRICA) (2015) Sorghum and green grams. https://www.farmafrica.org/ downloads/sgg-fact-sheetfa-sm.pdf (accessed April 2018).
31. Nzuma J (2016) Pulses sector investment profile: Kenya. http://www.intracen.org/uploadedFiles/intracenorg/Conte nt/Redesign/Projects/SITA/SITA_Kenya_Pulses_booklet_ final_web_page.pdf (accessed April 2018).

32. Taruvinga A \& Nengovhela R (2015) Consumers' perceptions and consumption dynamics of African Leafy Vegetables (ALVs): evidence from Feni Communal Area, Eastern Cape Province, South Africa. Int Conf Biomed Eng Technol 81, 89-95.

33. Muhanji G, Roothaert RL, Webo C et al. (2011) African indigenous vegetable enterprises and market access for small-scale farmers in East Africa. Int J Agric Sustain 9, 194-202.

34. Kalyanaram G \& Winer R (1995) Empirical generalizations from reference price research. Mark Sci 14, G161-G169.

35. Government of Kenya (2011) National food and nutrition security policy. https://extranet.who.int/nutrition/gina/sites/ default/files/KEN\%202011\%20National\%20Food\%20and\%20 Nutrition\%20Security\%20Policy\%5B1\%5D.pdf （accessed November 2017).

36. Herforth AW (2010) Promotion of traditional African vegetables in Kenya and Tanzania: a case study of an intervention representing emerging imperatives in global nutrition. $\mathrm{PhD}$ Thesis, Cornell University; available at https://ecommons. cornell.edu/handle/1813/17139

37. Abukutsa-Onyango M (2010) African indigenous vegetables in Kenya: strategic repositioning in the horticultural sector. https://www.researchgate.net/publication/235323508_African_ indigenous_vegetables_in_Kenya_strategic_repositioning_in_ the_horticultural_sector (accessed April 2018).

38. Omoro W (2013) Factors for low sorghum production: a case study of small-scale farmers in East Kano sub location, Nyando District, Kenya. http://edepot.wur.nl/279062 (accessed November 2018).

39. Ogeto R, Mshenga P, Cheruiyot E et al. (2012) Influence of institutional factors on sorghum production in Nakuru County, Kenya. J Agric Econ Dev 1, 130-137.

40. Chepng'etich E, Nyamwaro SO, Bett EK et al. (2015) Factors that influence technical efficiency of sorghum production: a case of small holder sorghum producers in lower Eastern Kenya. Adv Agric 2015, 861919.

41. van der Lans C, Snoek H, de Boer F et al. (2012) Vegetable chains in Kenya: production and consumption of vegetables in the Nairobi metropolis. http://edepot.wur.nl/216710 (accessed November 2018). 